\title{
Yoksulluk ile Mücadelede Vergi Politikalarının Rolü
}

\author{
İrem DiDiNMEZ ${ }^{1}$
}

\section{Öz}

\begin{tabular}{|c|}
\hline Mavkiew Article \\
\hline Başvuru Tarihi \\
\hline Ka.07.2021 \\
\hline Kabul Tarihi \\
\hline 17.09 .2021 \\
\hline DOI \\
\hline 10.53306/klujfeas.976450 \\
\hline JEL Kodu \\
\hline E62, K34, O17 \\
\hline
\end{tabular}

Bu çalışmada yoksulluk sorunu ile mücadelede kullanılan vergi düzenlemelerinin değerlendirilmesi amaçlanmaktadır. Günümüz toplumlarının önemli sorunlarından biri olarak gösterilen yoksulluk ekonomik boyutunun yanı sıra sosyal, siyasal ve psikolojik boyutları olan çok yönlü bir kavramdır. Farklı gelişmişlik düzeylerinde bulunan ülkelerde önemli sorunlar arasında yer alan yoksulluk, bazı ülkelerde refah devleti anlayışının yerleşmesi ile birlikte sosyal politikalar arasında yer edinmiştir. Sosyal refah devlet anlayışının benimsendiği devletlerde, özellikle ekonomi alanına doğrudan müdahale edilerek kamu harcamaları ve vergiler gibi politika araçları kullanılarak yoksulluk sorunu ile mücadele edildiği görülmektedir. Ekonomik ve siyasal istikrarın sağlanması, büyüme ve kalkınma hedeflerine ulaşılması ve gelir dağılımında adaletin sağlanması amaçları ile dolaylı-dolaysız vergiler, düz oranlı- artan oranlı- azalan oranlı vergi düzenlemeleri gibi farklı uygulamalar ile sübjektif ve objektif unsurlar dikkate alınarak maliye politikasının sosyal amacı doğrultusunda vergi sistemleri şekillendirilmektedir. Böylece belirlenen politika hedeflerine ulaşmak amacıyla vergilerin sosyal amaçları ile yoksulluk sorununun ortadan kaldırılması için önemli adımlar atılmaktadır.

Anahtar sözcükler: Yoksulluk, sürdürülebilir kalkınma, sosyal politika, maliye politikası, vergi

\footnotetext{
${ }^{1}$ Dr. Öğretim Üyesi, Hacettepe Üniversitesi İktisadi ve idari Bilimler Fakültesi, Maliye Bölümü, Mali Hukuk Anabilim Dalı, iremdidinmez@hacettepeedu.tr, ORCID: 0000-0002-1931-0688
} 


\title{
The Role of Tax Policies to Fight Against Poverty
}

\author{
İrem DiDINMEZ ${ }^{2}$
}

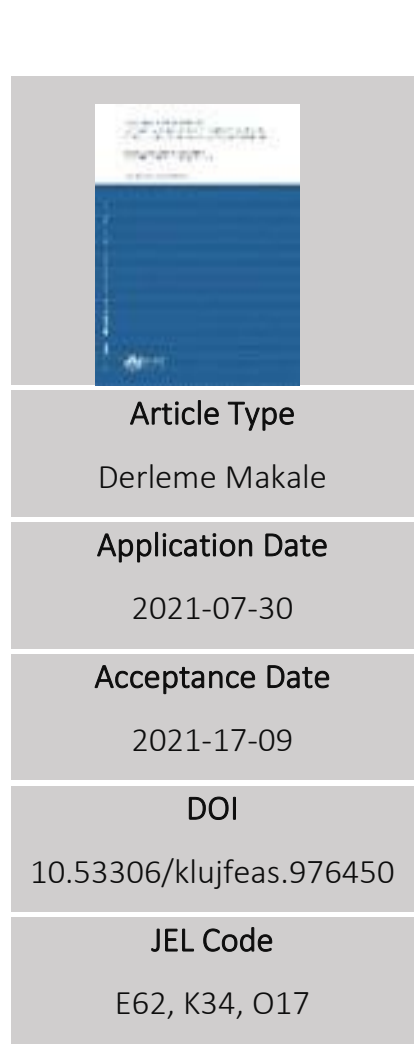

\section{Abstract}

In this study, it is aimed to evaluate the tax regulations used in the fight against the problem of poverty. Poverty, which is considered one of today's critical problems in a wide range of countries with different development levels, is a multi-dimensional concept with social, political, and psychological aspects and the economic one. It has taken its place among social policies with the establishment of the welfare state understanding. In social welfare states, it is seen that the problem of poverty is struggled with policy tools such as public expenditures and taxes, by directly intervening in the economy. Taxation systems are shaped in line with the social purpose of fiscal policy, taking into account different practices such as indirect-direct taxes, flat- progressive- regressive rate taxation regulations, and subjective and objective factors with the aim of ensuring economic and political stability, achieving growth and development goals and ensuring justice in income distribution. Thus, important steps are taken to eliminate the problem of poverty with the social purposes of taxes in order to achieve policy goals.

Key words: Poverty, sustainable development, social policy, fiscal policy, tax

\footnotetext{
2 Assist Prof., Hacettepe University Faculty of Economics and Administrative Sciences, Department of Finance, Department of Fiscal Law,, iremdidinmez@hacettepe.edu.tr, ORCID: 0000-0002-1931-0688
} 


\section{Giriş}

Birleşmiş Milletler (BM) tarafından 1987 yılında yayınlanan "Ortak Geleceğimiz" adlı raporda şimdiki ve gelecekteki nesillerin ihtiyaçlarının dikkate alınarak mevcut intiyaçların karşılanmasını mümkün kılan sistemler, sürdürülebilir kalkınma çerçevesinde şekillenen sistemler olarak nitelendirilmektedir. Sürdürülebilir kalkınma kavramı, çevre, sosyal güvenlik, sosyal hizmetler, barınma, doğal kaynaklar, sosyo-ekonomik politikalar, cinsiyet eşitliği, yoksulluk ile mücadele, kaliteli ve sağlıklı yaşam standartları, gıda güvenliği, eğitimde fırsat eşitliği, üretim ve tüketim süreçleri gibi ekonomik, sosyal ve politik pek çok konuyu kapsamaktadır. Bu çerçevede sürdürülebilirliğin sağlanabilmesi için uluslararası işbirliği ile ekonomik ve mali yapının sosyal yapıyı destekleyecek şekilde tasarlanması önem taşımaktadır. Bu kapsamda Dünya Bankası, BM, Uluslararası Para Fonu gibi pek çok kuruluş az gelişmiş ülkelere ve gelişmekte olan ülkelere dış yardımlar sağlayarak destek vermektedir. Dünya Bankası pek çok ülkeye gıda, eğitim, barınma ve kredi imkanlarının artırılması için yoksullukla mücadele programları ile destek sunarken; BM "Sürdürülebilir Kalkınma Hedefleri" doğrultusunda 2030 yılına kadar yoksulluğun ortadan kaldırılmasına yönelik politikaların önemine vurgu yapmaktadır.

BM'in 2015 yılında başlattığı 2030 yılı "Sürdürülebilir Kalkınma Hedefleri”nin önceliklerinden biri yoksulluk sorununun ortadan kaldırılarak tüm dünyada sağlıklı bir gezegende herkesin barış, refah ve fırsat eşitliği içinde yaşamasıdır. Bu kapsamda 2030 yılına kadar yoksulluğu her bir birey için ortadan kaldırmak, ulusal yoksulluk tanımları çerçevesinde yetişkin ve çocuk yoksulluğunu yarı yarıya azaltmak, gerekli kesimlere sosyal koruma programları uygulamak, temel hak ve özgürlükler çerçevesinde cinsiyet ayrımı gözetmeksizin herkese temel ihtiyaçlarını karşılayacak kaynakları sağlamak, ani değişikliğe neden olabilecek doğal afetler ile mücadele etmek hedeflenmektedir.

Sürdürülebilirlik hedeflerini gerçekleştirebilmek için yoksulluk gibi sosyal sorunlar ile mücadele çerçevesinde toplumsal ihtiyaçların karşılanması ve sosyal refahın maksimize edilmesi amacı ile politikalar geliştirmeye başlayan devletler daha fazla kamu harcaması yapmak zorunda kalmış ve bu kamu harcamalarının finansmanının sağlanması için daha fazla kamu gelirine ihtiyaç duymaya başlamıştır. Bu bağlamda devletler barınma, eğitim, yiyecek, sağlık hizmeti sunmak gibi sosyal amaçlar ile harcamalar yaparak toplumda yeterli kaynağa erişimi olmayan gruplara yönelik transfer harcamaları gerçekleştirmişlerdir. Bahsi geçen harcamaların finansmanı için gereken kamu geliri ihtiyacı ise genellikle vergiler ile karşılanmaktadır. Finansman kaynağı olarak vergilerin tercih edilmesinin nedeni borçlanma gibi diğer gelir getirecek kaynaklara kıyasla ekonomi ve sosyal yapı üzerinde daha az bozucu etkiye yol açması, sürdürülebilir olması ve uzun vadede sosyal refahta azaltıcı etkiye neden olmamasıdır. Böylece hem toplumsal refah maksimize edilebilecek hem de toplumdaki her bir bireyin topluma entegrasyonu sağlanarak hedefler ile uyumlu sonuçlara ulaşılabilecektir.

Literatürde yoksulluk sorunu ile mücadele konusunu inceleyen çok sayıda çalışma olmasına rağmen bu çalışmaların yoksulluk ve yoksulluk ile mücadeleye ekonomik bir bakış açısı ile odaklandıkları görülmektedir. Bu nedenle çalışmada yoksulluk ile mücadele konusuna vergilerin sosyal amacı çerçevesinde yaklaşılarak teorik bir bakış açısı ile değerlendirme yapılması amaçlanmaktadır. Bu kapsamda çalışmada öncelikle yoksulluk kavramı üzerinde 
durulacak; ardından sürdürülebilir kalkınma hedefleri ile ilişkili olarak yoksulluğun boyutu açıklanacak; daha sonra sosyal politikaların yoksulluk ile ilişkisi ortaya koyulacak; ardından yoksulluk ile mücadele yaklaşımları ele alınacak ve son olarak sosyal bir politika aracı olarak vergilerin yoksulluk sorunu ile mücadeledeki rolü değerlendirilecektir.

\section{Yoksulluk Kavramı}

Gelişmiş, gelişmekte olan ya da az gelişmiş ülke grupları fark etmeksizin tüm ülkelerde yoksulluk sorunun olması yoksulluk ile mücadele konusunun ulusal ve uluslararası boyutta ele alınmasına neden olmuştur. Bu bağlamda yoksulluk tarihsel süreç içinde kapsamı, nedenleri ve içeriği değişen bir kavram olarak karşımıza çıkmaktadır ve farklı şekillerde tanımlanmaktadır.

Yoksulluğa ilişkin tanımlamalar incelediğinde genellikle yoksulluğun gelir düzeyi ile ilişkili olarak ele alındığı görülmektedir. Yoksulluk ile ilgili ilk sistematik çalışmalardan biri olan Rowntree'nin (1901) çalışmasında yoksulluk, insanın fizyolojik ihtiyaçlarının karşılanmasına yetecek düzeyde gelire sahip olmaması şeklinde tanımlanmaktadır. Zastow’a (2015) göre ise gelir düzeyi ile ilişkilendirilen yoksulluk; insanların sosyal, ekonomik, psikolojik ve kültürel pek çok alanda ortalamanın altında bir hayat yaşaması anlamına gelmektedir. Benzer şekilde Seyyar (2002) da diğer insanlara kıyasla daha düşük düzeyde gelir elde edilmesi nedeniyle insan onuruna yaraşır bir seviyenin altında hayat sürülmesini yoksulluk olarak ifade etmektedir. Bir başka tanıma göre de yoksulluk, insanların giyinmeden yiyeceğe, barınmadan sağ|ığa, eğitimden güvenliğe kadar en temel ihtiyaçlarını karşılayacak kaynağa sahip olmamasıdır (Topgül, 2013).

Yoksulluk kavramının tanımlanmasında ve ölçülmesinde uluslararası çalışmalar arasında Birleşmiş Milletler Kalkınma Programı (United Nations Development Programme (UNDP))'nın çalışmaları ön plana çıkmaktadır. BM tarafından yürütülen çalışmalarda yoksulluk sorunu sadece gelir ile ilgili olarak değil; daha detaylı bir analiz ile sürdürülebilir kalkınma çerçevesinde ele alınmaktadır. 2015 yıında Birleşmiş Millet Kalkınma Zirvesi'nde kabul edilen "Sürdürülebilir Kalkınma Hedefleri" arasında ilk sırada "yoksulluğun olmaması" yer almaktadır. 2000 yılında BM'in belirlediği "Milenyum Kalkınma Hedefleri”nin devamı niteliğinde olan "Sürdürülebilir Kalkınma Hedefleri" yoksulluk sorunu ile mücadele edilmesi, cinsiyet eşitliği, eğitim, sağlık gibi beşeri sermayenin gelişmesine yönelik alanlarda fırsat eşitliğinin sağlanması, salgın hastalıklarla mücadele edilmesi ile sürdürülebilir ekonomik büyüme ve kalkınmanın gerçekleştirilmesi amaçlarına odaklanmaktadır. Yoksulluğun ekonomik, sosyal, kültürel ve politik pek çok boyutunun olması, herkes için yoksulluğun ortadan kaldırılması hedefinin, sürdürülebilir kalkınmanın ilk sırasında yer almasına neden olmuştur. Bu kapsamda UNDP’ye (1998) göre yoksulluk, insani gelişme için gereken hayat boyu sağlıklı bir yaşam, özgürlük, özgüven ve saygınlık, yaratıcı bir hayat ve hayat standardının ortalama bir şekilde korunması ve sürdürülmesi gibi zorunlu fırsatları ifade etmektedir. Bir başka deyişle, bir ailenin ya da bireyin temel ihtiyaçlarını karşılayacak imkanlara sahip olmaması, gidecek bir okul veya kliniğin olmaması, kişinin yiyecek yetiştireceği arazinin veya geçimini sağlayacak bir işinin olmaması ve gerektiğinde krediye erişiminin olmaması yoksulluk olarak değerlendirilmektedir. Bu çerçevede yoksulluk, insanların topluma etkin bir şekilde katılmak için yeterli kapasiteye sahip olmaması durumudur. 
Genel bir değerlendirme ile yoksulluk, toplumsal olarak algılanan gereksinimlerin eksiliğini ifade etmektedir. Yapılan açıklamalar kapsamında yoksulluğun, ihtiyaçların yeterli düzeyde karşılanamaması, maddi imkanların eksikliği nedeniyle ihtiyaçların karşılanmasında sorunların ortaya çıkması ve ihtiyaçların sosyal olarak tanımlanması, olmak üzere üç temel unsuru olduğu görülmektedir. Bu bağlamda farklı nedenleri olmakla birlikte yoksulluk içinde yaşayan insanların yaşam standartlarının kabul edilebilir bir asgari standardın altına olduğu kabul edilmektedir.

\subsection{Yoksulluk Türleri}

Yoksulluğun farklı gelişmişlik düzeylerinden ülkeleri etkileyen küresel bir sorun olarak görülmesi ve ekonomik, sosyal ve politik boyutlarının önem taşıması yoksulluk kavramının kapsamının genişlemesine ve farklı yoksulluk türlerinin ortaya çıkmasına neden olmuştur. Literatürde yoksulluk ile ilgili yapılan çalışmalar incelendiğinde mutlak yoksulluk, göreli yoksulluk, objektif yoksulluk, sübjektif yoksulluk, kentsel yoksulluk, kırsal yoksulluk ve insani yoksulluk gibi pek çok yoksulluk türü ile karşılaşılmaktadır.

Bu çerçevede ele alınan ilk yoksulluk türü mutlak yoksulluktur. Mutlak yoksulluk, ülkelerin kalkınma hedeflerine ulaşması bakımından önem taşımaktadır ve bireyler tarafından elde edilen gelirin temel ihtiyaçları karşılayacak düzeyde olmaması nedeniyle bireylerin yoksulluk sınırının altında olması anlamına gelmektedir (Bourguignon, 2004). Bir başka deyişle mutlak yoksulluk, fiziksel ve sosyal olarak gerekli intiyaçları karşılamak üzere belirlenmiş sabit bir satın alma gücüne sahip olunmamasıdır (Şenses, 2014). Başlangıçta gıdaya yönelik tüketim harcamaları ile ilişkilendirilen mutlak yoksulluk daha sonra eğitim, sağlık gibi diğer fiziksel gereksinimleri de kapsayacak şekilde daha geniş anlamda ele alınmaya başlamıştır. Zastrow'a (2015) göre ise mutlak yoksulluk, yaşamın en temel gereksinimlerinden yoksun olan insanları ifade etmektedir ve barınma, yiyecek veya giyecek gibi temel gereksinimlerini karşılayamayan kişi veya ailelerin sayısının tahmin edilmesiyle ölçülmektedir.

Yoksulluğun parasal boyutunun yanı sıra sosyo-psikolojik boyutuna özellikle uluslararası alanda vurgu yapılması bir diğer yoksulluk türü olan göreli yoksulluk kavramının gündeme gelmesine neden olmuştur. Göreli yoksulluk, sınırı iyi tanımlanmış bazı temel ihtiyaçlar açısından değil; nüfustaki belirli bir gelir standardının sabit bir oranı olarak ortalama gelir ya da medyan gelir gibi kavramlar ile tanımlanmaktadır (Bourguignon, 2004). Göreli yoksullukta bireylerin mevcut durumları toplumdaki diğer bireyler ile karşılaştırılmaktadır. Göreli yoksullukta bireylerin içinde yaşadıkları toplumda kabul edilen asgari yaşam düzeyinin altında olan bireyler yoksul kabul edilmektedir. Bu çerçevede göreli yoksulluk, toplumdaki gelir dağılımı ve refah düzeyi farklılıklarına odaklanmaktadır. Sen'e (2002) göre yoksulluk, mutlak ve göreli yoksulluk koşullarını içeren yeniden dağıtımcı bir adalet sorunudur. Bu durum "yoksulluğun" sosyal bir varlık olan insan ihtiyaçlarının karşılanması bakımından daha geniş kapsamlı bir kavram olduğuna işaret etmektedir.

Mutlak yoksulluk ve göreli yoksulluk türleri ile ilişkili olan bir diğer ayrım objektif ve sübjektif yoksulluktur. Objektif yoksulluk insanların mutlak veya göreli olarak belirli hayat standardının altında olduğu durumda; sübjektif yoksulluk ise bireylerin kendilerini diğerlerine kıyasla daha 
düşük imkanlara sahip olarak değerlendirmeleri durumunda ortaya çıkmaktadır (Lipton, 1997).

Sosyal ve ekonomik eksikliklerin ortaya çıktığı mekana göre ayrım yapıldığında ise kırsal ve kentsel yoksulluk türleri ile karşılaşılmaktadır. Kırsal yoksulluk, kırsal bölgelerde işsizlik sorunu ile ilgili olarak ortaya çıkan yaygın eksik istihdam, çalışanların hukuki haklarının yeterince tanımlanmaması, işgücünün korunmaması, yeterli sosyal korunmanın sağlanamamamış olması ve kırsal bölgelerde yaşayanların gelir düzeylerinin düşüklüğü nedeniyle karşı karşıya kalınan yoksulluğu ifade etmektedir (ILO, 2008). Kırsal alanda yoksulluğun artması, çalışanların önemli bir kısmının tarım faaliyetlerinden gelir elde etmesi ve iklim değişikliği sorununun tarımsal üretim alanında ortaya çıkardığı sorunlar kırsal alanlardan kentlere göçün yaşanmasına neden olmuş ve bu durum kentsel yoksulluk sorununu ortaya çıkarmıştır (Helgason, 2020). Kentsel yoksulluk, sanayileşmiş şehirlerde bulunan, konforlu yaşam standartlarının oluşturulması, bireyselliğin artması, toplumsal parçalanma ve ikilileşme gibi süreçlerin kombinasyonunun sonucu olan bir dizi ekonomik ve sosyal zorluklara atıfta bulunmaktadır (Cano-Hila, 2020).

Yapılan açıklamalar çerçevesinde yoksulluğun pek çok boyutuna vurgu yapılması yoksulluğun kapsamının daha detaylı incelenmesine neden olmuştur. Böylece yoksulluk gelirin yanı sıra sağlık ve eğitim olanaklarının yetersizliği, bilgi ve iletişim yoksunluğu, insani ve siyasi hakların kullanılamaması, haysiyet, güven ve öz saygının yokluğu gibi pek çok unsur ile ilişkili olarak ele alınmaya başlamıştır (UNDP, 1997). Yoksulluğun bir insan hakları ihlali olduğu son dönemlerde özellikle vurgulanmaktadır (OHCHR, 2004). Bu durum, yoksulluk kavramının insani gelişmişlik ile ilişkilendirilmesine yol açmıştır. 1997 yılında UNDP İnsani Gelişmişlik Raporu'nda yer verilen İnsani Yoksulluk Endeksi, yoksulluğu, gelir yoksulluğundan ayırmış ve "insani yoksulluk" kavramı gündeme gelmiştir. İnsani yoksulluk, okuryazarlıktan beslenme olanaklarına anne- çocuk sağlığından salgın hastalıklara ortalama yaşam süresinden temel insani yeteneklerin eksikliğine kadar pek çok konu ile ilişkilidir. Bu durum bireysel ve toplumsal etkileri olan yoksulluk ile mücadele edebilmek için yoksulluğun ekonomik ve ekonomik olmayan boyutlarının net bir şekilde ortaya koyulmasını gerektirmektedir (Horejsi ve Sheafor, 2015).

\section{Son Dönemlerde Küresel Düzeyde Yoksulluğun Boyutu}

2030 yılına kadar, ulusal tanımlara göre tüm boyutlarıyla yoksulluk içinde yaşayan her yaştan erkek, kadın ve çocukların oranını en az yarı yarıya azaltmak sürdürülebilirlik hedefleri açısından önem taşımaktadır.

1990 ile 2015 yılları arasında aşırı yoksulluk içinde yaşayan insan sayısı oranında düşüş yaşanmış olmasına rağmen pek çok insan hala temel ihtiyaçlarını karşılayabilmek için mücadeleye devam etmektedir. 2010 yılında \%15,7 olan aşırı yoksulluk içinde yaşayan dünya nüfusu 2015 yılında \%10,0'a; 2017 yılında ise \% 9,3'e gerilemiştir (United Nations, 2020). Ancak son dönemlerde özellikle küresel düzeyde önemli bir sorun olan yoksulluğun azalma hızında yavaşlamalar olduğu görülmektedir.

Yoksulluk ile mücadele konusunda yaşanan sorunlar 2019 yılında tüm dünyayı etkisi altına alan Covid- 19 salgını ile farklı bir boyut kazanmış ve yoksulluk ile mücadele konusunda 
ülkelerin beklenen ilerlemeyi kaydedemesine yol açmıştır. Ülkeler tarafından açıklanan sosyal politikalar aracılığı ile pandemi döneminde çok sayıda insana destek sağlanmış olmasına rağmen 4 milyardan fazla insan bu desteklerden yararlanamamıştır (United Nations, 2021b). Koronavirüs pandemisinin etkileri ile yoksulluğun azaltılmasında kaydedilen ilerlemenin önemli bir kısmı tersine çevrilerek 1990'lı yılların sonlarındaki Asya Krizi'nin ardından 2020 yılında ilk kez küresel düzeyde aşırı yoksullukta artış yaşanmıştır (United Nations, 2021a, s. 26). Yapılan araştırmalara göre aşırı yoksulluk oranı 2019 yılında \%8,2, 2020 yılında ise \%8,8'dir (United Nations, 2020, s. 24). BM'in 2021 yılı Sürdürülebilir Kalkınma Hedefleri Raporu'na göre 2020 yılında ek 119-124 milyon insanın aşırı yoksulluk içinde yaşadığı ve aşırı yoksulluk ile mücadelede belirlenen hedefin gerisinde kalındığı ifade edilmiştir. Yapılan tahminlere göre 2030 yılında aşırı yoksulluk oranının \%7 olması beklenmektedir (United Nations, 2021b). Bu durum 2030 yılında aşırı yoksulluğun sona erdirilmesine ilişkin sürdürülebilir kalkınma hedefine ulaşılamayacağını göstermektedir.

Covid- 19'dan önce dahi ülkelerin 2030 yılına kadar yoksulluğu sona erdirme hedefine ulaşma yolunda yeterli ilerlemeyi gösterememiş olması bu konuda acil ve önemli eylem planlarının hazırlanması gerekliliğini vurgulamaktadır. Covid- 19 pandemisi ile birlikte 71 milyondan fazla insanın aşırı yoksulluk içinde yaşayacağına ilişkin tahminler salgının ekonomik etkileri daha güçlü bir şekilde hissedilmeye başladıkça, yoksulları ve savunmasızları korumak için sosyal politikaların önemini artmıştır (United Nations, 2020, s. 24). Böylece yoksulluk, sosyal politikalar arasında yeniden gündeme gelmiş ve mücadele edilmesi gereken sosyal sorunlar arasında üst sıralarda yerini almıştır (Buğra, 2008).

\section{Yoksulluk Sorunu ve Sosyal Politikalar}

Yoksulluk kavramının devletler tarafından sosyal bir sorun olarak ele alınmaya başlandığı dönem 1300'lü yıllarda İngiltere'de uygulanan "Yoksulluk Kanunları"na dayandırılsa da Keynesyen ekonomi döneminde kurumsallaşan refah devletleri ile birlikte yoksulluk, sosyal refahın maksimizasyonu kapsamında üzerinde daha çok durulan konulardan biri olmuştur. Bireysel ihtiyaçların yanı sıra toplumsal ihtiyaçlarda ortaya çıkan artış sosyal refahın gözetilmesi amacı ile devletlerin adalet, güvenlik gibi hizmetlerin yanı sıra sosyal alanda da rol üstlenmesine yol açmıştır. Bu kapsamda toplumda yaşayan her bir bireye belirli düzeyde gelir, sosyal güvence ve kamu mal ve hizmeti sunulmasına ilişkin düzenlemeler ile piyasalar yönlendirilerek; ayrımcılığın olmadığı, eşitlikçi, demokratik bir düzen ile şekillenen standartlar çerçevesinde yaşama imkanı sağlanmasına yönelik politikalar geliştirilmesi amaçlanmaktadır (Briggs, 1961, s. 228). Böylece refah devletleri, ekonomide verimliliğin ve etkinliğin sağlanması, tam istihdam hedefine ulaşılması, benimsenen politikaların sürdürülebilirliğinin sağlanması, mevcut kaynakların yeniden dağıtımı, gelir dağılımında adaletsizlik sorunun çözülmesi, sosyal entegrasyonun sağlanması, ekonomi alanında olduğu gibi sosyal alanda da istikrar sağlanarak yoksulluğun azaltılması amaçları doğrultusunda politikalar uygulamaya başlamışlardır (Headey vd., 1999).

Sosyal refah devleti anlayışının yaygınlaştığı 1929 Büyük Buhranı sonrası dönemlerden bu yana insanların birbiri ile nasıl etkileşime girdiği de dahil olmak üzere insan hayatının pek çok boyutu sosyal, ekonomik ve politik alanda araştırma konusu yapılmıştır. Yoksulluğun ekonomik, sosyal ve politik boyutlarının olması yoksulluk ile mücadele için geliştirilen politika 
araçlarının da çok yönlü olması gerekliliğini ortaya çıkarmaktadır. Yoksulluk, yalnızca fiziksel olarak hayatta kalmak için yetersiz kaynaklara sahip olmak anlamına gelmemekte; aynı zamanda yaşam standartlarını göz önünde bulundurarak bir topluluğa tam entegrasyonu engelleyen koşulların bir bütünü olarak ifade edilmektedir. Bu nedenle yoksulluk sorunu ile mücadele ederken sosyal politika araçlarının aktif kullanılması önem taşımaktadır.

Devletlerin toplumda eşitlik, adalet, refah ve sosyal alanda korumanın sağlanması amacı ile uyguladığı politikalar sosyal politikalardır (Alcock, 2008, s. 4-5). Bu kapsamda ülkeler yoksulluğun ortadan kaldırımasını etik, sosyal, politik ve ahlaki bir zorunluluk olarak kabul etmişler ve kalkınmanın sürdürülebilir olması için toplum refahının göz önünde bulundurulduğu politikaları uygulamayı tercih etmişlerdir.

Gelişmiş ülkelerden gelişmekte olan ülkelere kadar tüm ülke gruplarında yoksulluğun yaşanması yoksulluk ile mücadelede ülkelerin politikalar geliştirmesine neden olmuştur. Aşağıda yer alan Tablo 1'de yoksulluk sorunu ile mücadele için de önem taşıyan eski ve yeni politika araçları gösterilmektedir.

Tablo 1. Eski ve Yeni Politika Araçları

\begin{tabular}{|c|c|c|c|}
\hline \multirow{3}{*}{ Aile Politikası } & \multirow{2}{*}{$\begin{array}{c}\begin{array}{c}\text { Eski Sosyal } \\
\text { Politikalar }\end{array} \\
\text { Gelir ve İş Koruma } \\
\text { Politikaları }\end{array}$} & \multicolumn{2}{|c|}{ Yeni Sosyal Politikalar } \\
\hline & & $\begin{array}{l}\text { Aktifleştirme/Sosyal } \\
\text { Yatırım Politikaları }\end{array}$ & $\begin{array}{l}\text { İhtiyaç Odaklı } \\
\text { Sosyal Koruma } \\
\text { Politikaları }\end{array}$ \\
\hline & $\begin{array}{l}\text { Çocuk ve aile payı } \\
\text { (transferler) }\end{array}$ & $\begin{array}{l}\text { Çocuk ve yaşlı bakım } \\
\text { hizmetleri } \\
\text { Doğum izni }\end{array}$ & $\begin{array}{lr}\text { Düşük } & \text { gelirliler } \\
\text { için } & \text { sübvanse } \\
\text { edilmiş } & \text { çocuk } \\
\text { bakım hizmeti }\end{array}$ \\
\hline $\begin{array}{l}\text { İşgücü } \\
\text { Piyasası/İşsizlik } \\
\text { Politikası }\end{array}$ & $\begin{array}{l}\text { Pasif destekler } \\
\text { (içeridekiler) } \\
\text { İstihdamın } \\
\text { korunması }\end{array}$ & $\begin{array}{l}\text { Aktif işgücü piyasası } \\
\text { Beşeri sermayeye eğitim } \\
\text { desteği }\end{array}$ & $\begin{array}{l}\text { İşsizler(uzun } \\
\text { süreli) için ihtiyaç } \\
\text { odaklı gelir } \\
\text { desteği }\end{array}$ \\
\hline Emeklilik Politikası & $\begin{array}{l}\text { Aylık bağlama } \\
\text { (içeridekiler) }\end{array}$ & $\begin{array}{l}\text { Dışarıdakiler için emeklilik } \\
\text { sigortası }\end{array}$ & $\begin{array}{l}\text { Çocuk büyütmede } \\
\text { emeklilik kredisi } \\
\text { Evrensel asgari } \\
\text { emeklilik }\end{array}$ \\
\hline Maluliyet Sigortası & $\begin{array}{l}\text { Aylık bağlama } \\
\text { (transfer) }\end{array}$ & Entegrasyon politikaları & \\
\hline Sosyal Yardım & $\begin{array}{l}\text { Yoksulluk yardımı } \\
\text { (transferler) }\end{array}$ & $\begin{array}{l}\text { Aktifleştirme ve yeniden } \\
\text { entegrasyon programları }\end{array}$ & $\begin{array}{l}\text { Çalışan yoksullara } \\
\text { gelir desteği } \\
\text { (negatif gelir } \\
\text { vergisi vb.) }\end{array}$ \\
\hline
\end{tabular}

Kaynak: Häusermann, 2012, s. 6 
Tablo 1'e göre ülkeler tarafından kullanılan sosyal politika araçlarının bir kısmı kuramsal düzen ile bir kısmı ise sosyal kamu harcamalarının yönetilmesi ile ilgilidir. Sosyal sorunların çözümünde benimsenen politikaların değişen koşullara göre şekillenmesi son dönemlerde transfer odaklı politikalar yerine hizmet odaklı politikaların benimsenmesine yol açmıştır (Huber ve Stephens, 2006, s. 143). Tablo 1'de yer alan politika araçları kullanılarak toplumda gelir dağılımında adalet ve eşitlik sağlanabilecek, verimlilik artışı ortaya çıkacak, eğitim ve sağlıkta fırsat eşitliği sağlanabilecek ve sosyal refahın maksimize edilmesi hedefi gerçekleştirilebilecektir (Sinn, 1994, s. 1-2). Böylece sadece kronik yoksulluk sorunu ile mücadelenin yanı sıra toplumdaki dezavantajlı grupların hayat koşullarının detaylı bir şekilde analiz edilerek yoksulluk ile mücadelede hedefler ile uyumlu sonuçlara götürecek politikalar belirlenebilecektir (Saraceno, 2002).

\section{Yoksulluk ile Mücadele Yaklaşımları}

Yoksulluk sorunu ile mücadele için etkin politika araçlarının geliştirebilmesi amacıyla yapılan çalışmalarda öncelikle yoksulluğun nedenlerinin tespit edilmesi gerekmektedir. Yoksulluğun nedenlerini kapsamlı bir şekilde ortaya koyan Zastrow'a (2005) göre yoksulluk, iş gücü piyasasındaki sorunlar, gelir dağılımı dengesizlikleri, sağılık ve eğitim alanındaki yatırımların yetersizliği, uluslararası arenadaki rekabet, krizler, enflasyon gibi ekonomik kaynaklı olabileceği gibi demografik faktörler, sosyo-psikolojik faktörler, toplumsal ve bireysel sorunlar, nüfus, cinsiyet ayrımcılığı gibi sosyal nedenlerden de kaynaklanabilmektedir. Yoksulluğun ekonomik, sosyal ve siyasal farklı boyutlarının olması yoksulluk sorunu ile mücadele edilmesinde farklı yaklaşımların benimsenmesine neden olmuştur. Bu kapsamda ilk olarak temel alınacak yoksulluk yaklaşımının belirlenmesi önem taşımaktadır.

Atherton (1992) yoksulluk ile mücadele politikalarını uygulama sürelerine göre sınıflandırmıştır. Buna göre yoksulluk ile mücadele yaklaşımları, uygulamada olan politikaların tekrar değerlendirilmesi, sosyo- ekonomik yapı dikkate alınarak yeni politikaların geliştirilmesi için mevcut politikalarda değişiklik yapılması ve sosyal reformlardan yararlanılması olmak üzere üç bakımdan ele alınmıştır (Şenses, 2014, s. 219).

Drakakis-Smith (1996) ise yoksulluk ile mücadele kapsamında koruyucu ve geliştirici politikalar ile ilgili alanlara müdahale edilerek yoksulluk sorunu ile mücadele edilebileceğini öne sürmüştür. Bu kapsamda koruyucu politikalar yoksulluk sınırının altında ve yoksulluk sınırının çok az üzerinde olanların toplumsal düzende ortaya çıkabilecek olumsuz durumlar karşısında korunmasına odaklanırken; geliştirici politikalar ise vatandaşların uzun vadede eğitim, sağlık, barınma, giyinme gibi pek çok alana erişiminin kolaylaştırılması ve yaygınlaştırılmasına odaklanmaktadır.

Yoksulluk ile mücadele çerçevesinde genel kabul gören bir diğer yaklaşım ise dolaylı yaklaşım ve dolaysız yaklaşım olmak üzere ikiye ayrılmaktadır (Şenses, 2014, s. 219). Dolaylı yaklaşım, 1960'। yıllara kadar uygulanan ve yoksulluğu büyüme ile ilişkili olarak ele alan yaklaşımdır. Dolaylı yaklaşıma göre büyüme sağlandığında ve sürdürülebilir olduğunda hem düşük gelirli grupta yer alan yoksulların daha fazla gelir elde etmesi sağlanabilecek hem de hayat standardı yükselecektir (Bhagwati, 1988). Şenses'e (2014) göre büyüme hızı artırıldığında yoksulluk ile mücadelede etkili politikalar geliştirilebilecektir. Dolaylı yaklaşımda mutlak yoksulluğu hızla 
azaltma hedefine ulaşmak için güçlü, ülkeye özgü büyüme ve dağıtım politikaları kombinasyonlarının belirlenmesi önem taşımaktadır (Bourguignon, 2004, s. 1). Farklı gelişmişlik düzeylerinden ülkelerde büyüme hızlarının farklı olması ve büyümenin gelir dağıımına etkileri dikkate alındığında büyümenin hızlandığı dönemlerde gelir dağılımındaki eşitsizliklerin artması gibi nedenler gelir dağılımı eşitsizliği, büyüme ile yoksulluk arasındaki ilişkinin belirsiz olmasına neden olmuştur (Cardoso ve Helwege, 1992). Bir başka deyişle, gelir dağılımının daha dengeli olduğu ülkelerde büyüme yoksulluğun azalmasında etkili bir rol oynarken; gelir dağılımının dengeli olmadığı ülkelerde büyümenin yoksulluğu artırabileceğine ilişkin sonuçlara ulaşılmıştır (Şenses, 2014). Bu durum yoksulluk ile mücadelede 1970'li yıllardan itibaren dolaysız yaklaşımların ön plana çıkmasına yol açmıştır.

Dolaysız yaklaşımlar, devletin maliye ve iktisat politikası araçları ile doğrudan ekonomiye müdahalesi yoluyla yoksulluk ile mücadele edilmesini ifade etmektedir. Bu kapsamda devletler doğrudan bireylere destekte bulunarak gelirin yeniden dağıtımı politikaları ile yoksulluk sorununa çözüm getirmeye çalışmaktadır. Yoksulluk ile mücadele etmek amacı ile sosyal yardım politikaları, vergiler, kamu harcamaları, istihdam politikaları gibi araçlar ile yoksul kesimin refahını artıracak uygulamalar benimsenmektedir. Şenses'e (2014, s. 240) göre dolaysız yaklaşımların yoksulluk sorunu ile mücadelede başarılı olabilmesi için toplumda yoksullukla mücadelenin öncelikli amaçlar arasında yer alması ve bu kapsamda kullanılan politika araçlarının genel kabul görmesi, yoksul olarak nitelendirilenlerin doğru bir şekilde tespit edilmesi, hızlı, etkili, verimli bürokratik süreçlerin varlığı ve doğru politikaları seçebilen bürokratların ilgili alanlarda çalışması gerekmektedir.

Dolaysız yaklaşımlarda devletin ekonomi alanına doğrudan müdahale ederek adaletli bir gelir dağılımının sağlanmasına yönelik düzenlemeleri esas alınmaktadır. Bu çerçevede yapılan düzenlemeler incelendiğinde ihtiyaç duyulan gruplara yönelik sosyal harcamaların yapıldığı dikkat çekmektedir. Gelir dağılımında adaletin sağlanması amacı ile yapılan harcamalar ile özellikle yoksul olan kesime doğrudan sosyal yardım sunulmaktadır. Sosyal kamu harcamalarının artması ise devletlerin daha fazla gelir ihtiyacı duymasına neden olmaktadır. Artan sosyal harcamaların finanse edilmesi amacıyla borçlanma yolu tercih edildiğinde sosyal refahın olumsuz etkilenmesi durumu ile karşılaşılabileceği göz önünde bulundurulduğunda finansman için pek çok devletin vergi politikalarını tercih ettiği görülmektedir. Böylece vergiler maliye politikası aracı olarak sosyal politikaların gerçekleştirilmesi bakımından da işlev görmekte ve geliri yüksek olan kişilerden geliri düşük olan gruplara fon aktarımı gerçekleştirilerek gelirin yeniden dağıtımı sağlanabilmektedir.

\section{Yoksulluk ile Mücadele ve Sosyal Bir Politika Aracı Olarak Vergiler}

1929 Büyük Buhranı ile Keynesyen iktisadi düşüncenin sosyal refah devleti anlayışını kurumsallaştırması devletlerin ekonomi alanında daha fazla rol üstlenmesine neden olmuştur. Bu çerçevede devletin işlevleri, dağıtımda adaletin sağlanması, bölüşümde etkinliğin sağlanması ve ekonomik istikrarın sağlanması şeklinde ifade edilmiştir (Musgrave, 1959). Böylece kamu gelir ve harcama yönetimi ekonomi politikalarının yanı sıra sosyal politikaların yürütülmesinde de önem kazanmıştır. 
Bismarck tarafından 1880'li yıllarda gündeme getirilen "sosyal sigorta” uygulamalarının 1942 yılında Beveridge Raporu ile yeniden şekillendirilmesi sonucunda sosyal devlet anlayışı yerleşerek devletlerin sosyal alanda daha fazla rol üstlenmesine ve daha fazla sosyal politika uygulamasına neden olmuştur (Flora ve Heidenheimer, 2009). Böylece devletlerin mali amacın yanı sıra mali olmayan amaçlarla da ekonomiye yön verdiği düşüncesi yaygınlaşmıştır. Beveridge Raporu ile devletlerin eğitim, sağlık, barınma, gıda, sosyal hizmetler, çevrenin korunması, sosyal güvenlik, çevresel sorunlar ve yoksulluk ile mücadele kapsamında gerçekleştirdiği sosyal nitelikteki kamu harcamalarının finanse edilebilmesi için vergileme politikaları önem kazanmıştır (Karabacak, 2012, s. 226). Vergi düzenlemeleri aracılığı ile vergi yükünün toplumda adaletli ve dengeli bir şekilde dağıIması, gelir ve servetin yeniden dağıtımı yolu ile eşitlik ve adaletin sağlanması, ekonomik etkinlik, istikrar ve verimlilik hedeflerine ulaşılması, iktisadi kalkınma ve büyümede sürdürülebilirliğin sağlanması, gelir ve servet dağıtımında eşitsizliklerin giderilmesi gibi ekonomik ve sosyal amaçlar sosyal politikalara yön vermektedir (Aydın ve Türgay, 2011).

Sosyal refahın maksimize edilmesi için toplumda adalet ve eşitliğin tesis edilmesinde devletin mali alanda egemenlik yetkisini kullandığı vergilendirme konusunda adalet ve eşitliğin sağlanması önem taşımaktadır. Vergi adaleti ve eşitliğinin sağlanması için bireylerin mali güçleri dikkate alınarak vergi sistemlerinin tasarlanması gerekmektedir. Vergilemede eşitliğin iki boyutu vardır. Bu kapsamda yatay eşitlik için aynı durumda olanların aynı şekilde; dikey eşitlik için ise farklı durumda olanların farklı şekilde vergilendirilmesi gerekmektedir. Vergi adaleti için bireylerin mali güçleri bir başka deyişle ödeme güçleri göz önünde bulundurularak vergi sistemleri tasarlanmaktadır. Bireylerin kendisini ve ailesini geçindirecek kadarlık bir gelirin üzerindeki kısım olarak olarak ifade edilen ödeme gücünün göstergeleri gelir, harcama ve servettir (Şen ve Sağbaş, 2016, s. 13). Vergi ödeme gücüne ulaşmak için kullanılan teknikler yoksulluk ile mücadelede önem taşıyan unsurlar olarak ön plana çıkmaktadır. Bu kapsamda en az geçim indirimi, tarifeler, ayırma prensibi ile muafiyet ve istisnalardan yararlanılması gibi teknikler kullanılabilmektedir.

En az geçim indirimi, temelleri Montesquie'ya kadar dayanan ve hayatın sürdürülebilmesi için temel fizyolojik gereksinimleri karşılayacak kadar asgari düzeyde gelirin vergilendirilmemesini ifade etmektedir (Edizdoğan vd., 2013). En az geçim indirimi farklı şekillerde uygulanabilmektedir. Bu kapsamda en az geçim indirimi miktarı, vergi ödemekle yükümlü olanların kendisi, eşi ve çocukları göz önünde bulundurularak gelirden indirilerek vergi mahtrahına ulaşılıyorsa matrahtan indirim; vergi miktarından düşülüyorsa verginden indirim; kişinin kendisi, eşi ve çocuklarının sayısına bölünerek vergilendirme yapılıyorsa katsayı sistemi uygulanmış olmaktadır (Edizdoğan vd., 2013). En az geçim indirimi tekniğinden genellikle dolaysız vergiler arasında yer alan gelir üzerinden alınan vergilerde yararlanılmaktadır.

Vergi ödeme gücüne ulaşmak için kullanılacak bir başka yöntem tarifeler uygulamaktır. Vergi miktarının belirlenmesi için vergi matrahına uygulanan ölçülere tarife adı verilmektedir. Vergi adaletine ulaşmak için düz oranlı, azalan oranlı ve artan oranlı tarifeler kullanılmaktadır. Vergi oranın gelir düzeyi ile değişmediği, bir başka deyişle tüm gelir düzeylerine aynı vergi oranı uygulandığı takdirde düz oranlı; gelir düzeyi arttıkça vergi oranının azaldığı durumda azalan oranlı, gelir düzeyi arttıkça vergi oranının arttığında ise artan oranlı vergi tarifelerinden 
bahsedilmektedir. Gelir dağılımında adaletin sağlanması, toplumdaki gelir ve servet eşitsizliği sorununun ortadan kaldırılması ve yoksulluk ile mücadele edilebilmesi için sıklıkla artan oranlı tarifelerden yararlanıldığı görülmektedir. Bu kapsamda artan oranlı vergi tarifeleri, J. J. Rousseau, A. Wagner gibi bir çok bilim insanı tarafından toplumsal adaletin sağlanmasında marjinal fayda yaklaşımı esası çerçevesinde kabul görmektedir (Akdoğan, 2016, s. 246). Böylece vergileme konusunda da adalet gözetilerek yüksek gelir grubundaki bireylerden düşük gelir grubundaki bireylere kaynak transferi gerçekleştirilerek vergilemede adaletin tesis edilmesine katkı sağlanmaktadır.

Vergileme alanında adalete ulaşmanın bir diğer yöntemi ise ayırma prensibinden yararlanılmasıdır. Ayırma prensibinde verginin kaynağını oluşturan unsur dikkate alınmaktadır. Buna göre emek üzerinden elde edilen gelirin sermaye üzerinden elde edilen gelire kıyasla daha düşük oranda ya da miktarda vergilendirilmesi esastır. Böylece emek geliri, sermaye gelirinin karşısında korunmaktadır (Mutluer ve Kuzeyli Dayanç, 2019). Ayırma prensibinin uygulanması gerektiğine yönelik görüşlerin temel dayanakları emek gelirinin kişiye bağlı olması nedeniyle sürekli bir gelir türü olmaması, konjoktürel dalgalanmalardan sermaye gelirine kıyasla daha fazla etkilenmesi, emek geliri elde edenlerin vergi kaçırma ve vergiden kaçınma imkanlarının sınırlı olması, emek gelirinin marjinal değerinin sermaye gelirinden daha yüksek olması ve sosyal sınıflar arasında dengenin oluşturulmasına katkı sağlamasıdır (Mutluer ve Kuzeyli Dayanç, 2019, s. 78). Bahsi geçen olumlu özelliklerine rağmen ayırma prensibi karşıtı olanlar ise sermaye gelirinin azalmasına yol açması, sermaye geliri elde edenler üzerindeki vergi yükünü artırması, sermaye gelirinin ekonomik büyüme ve kalkınmada önemli rol oynadığı gerekçesi ile ayırma prensibine eleştiriler getirmektedir (Akdoğan, 2016, s. 257-259). 1907 yılında ilk olarak İngilitere'de uygulanan ve daha sonra diğer ülkelerin vergi sistemlerinde yer almaya başlayan ayırma prensibi zaman zaman yatay eşitlik ilkesinin önünde engel teşkil etse de özellikle sosyal adaletin sağlanması açısından savunulmaktadır (Edizdoğan vd., 2013, s. 257). Bu bağlamda özellikle gelişmiş ülkelerde emek geliri lehine uygulanan ayırma prensibi gelişmekte olan ülkelerde sermaye geliri lehine uygulanmaktadır.

Ekonomik, sosyal ve hukuki nedenlerle bir kısım vergi konularının ya da vergi mükelleflerinin vergi karşısında korunmaları yoluna gidilmesi vergilemenin bir sosyal politika aracı olarak kullanılması bakımından önem taşımaktadır. Vergi konularının vergilendirmenin dışında tutulması istisna; vergi mükelleflerinin vergilendirmenin dışında bırakılması ise muafiyet olarak adlandırımaktadır. Muafiyet ve istinaslara ilişkin hususların hukuki düzenlemeler ile belirlenmesi vergilerin kanuniliği ilkesinin bir gereği olmakla birlikte muafiyet ve istisnalara ilişkin düzenlemelerin hem vergi adaletine zarar vermeyecek hem de gelir dağılımında eşitsizlik yaratmayacak şekilde belirlenmesi önem taşımaktadır (Akdoğan, 2016; Edizdoğan vd., 2013). Ayrıca muafiyet ve istisnaların çok sayıda olması vergi sistemlerinin karmaşık olmasına neden olarak vergilerin açık, anlaşılır ve net olmasının önünde engel teşkil etmektedir. Bu nedenle sosyal refahın maksimize edilmesi için eşitlik ve adaletin gerçekleştirilmesinde muafiyet ve istisnaların kontrollü bir şekilde toplum dinamikleri ile uyumlu olarak uygulanması gerekmektedir. 
Vergileme alanında ödeme gücünün temel alınmasının yanı sıra sosyal alanda eşitliğin ve adaletin korunabilmesi için bir diğer unsur dolaylı- dolaysız vergi uygulamaları arasında dengenin sağlanmasıdır. Vergi sistemlerinde dolaylı vergilerin payının yüksek olması ekonomik istikrarın sağlanması, kaynak ve gelir dağılımında adaletin tesis edilmesi gibi maliye politikasının ekonomik ve sosyal amaçları ile ters düşen sonuçlar ile karşılaşılmasına neden olabilmektedir. Dolaylı vergi yükünün yüksek olduğu daha az gelişmiş toplumlarda vergi yükü düşük gelir gruplarının üzerinde kalırken; dolaysız vergilerin ağılıklı olarak benimsendiği gelişmişülke gruplarında vergi yükü daha yüksek gelirlilerin üzerindedir. Vergi yükünün daha yüksek gelir grupları üzerinde olması toplumsal adaletin gerçekleştirilmesine katkı sağlamaktadır (Grown, 2010). Bir başka deyişle, dolaysız vergilerin daha geniş uygulama alanı bulduğu ülkelerde gelirin ve servetin vergiler aracılığı ile yeniden dağılımı sağlanarak düşük gelir grupları lehine iyileşme sağlanabilmektedir (TÜSIAD, 2012). Bu nedenle dolaysız vergilerin yaygın olduğu vergi sistemlerinin yoksulluk ile mücadele konusunda daha başarılı olduğu görülmektedir.

İklim değişikliği sorunun neden olduğu doğal afetler gibi olumsuz durumlardan en fazla etkilenen kesimlerden birinin yoksullar olduğu düşünüldüğünde yoksulluk ile mücadele edilmesinde sürdürülebilir çevre politikalarının göz ardı edilmemesi gerekmektedir. Bu nedenle iklim değişikliği sorunu ile mücadele hem ulusal hem de uluslararası arenada üzerinde durulması gereken konular arasında yer almaktadır. Son dönemlerde sel baskınları, depremler, toprak kaymaları gibi doğal afetler sürdürülebilir büyüme ve kalkınma hedefleri kapsamında öncelikli alanlar arasında yer almaya başlamıştır (Türkiye Cumhuriyeti Cumhurbaşkanlığı Strateji ve Bütçe Başkanlığı, 2019, s. 199). Bu çerçevede karbon vergisi, motorlu taşıtlar vergisi, havayolu taşımacılığı vergisi gibi ulusal ve uluslararası düzeyde uygulanabilecek vergilerin iklim değişikliği sorunu ile mücadelede çözüm olabileceği düşünülmektedir. Bu amaçla Danimarka, İsveç, Norveç gibi pek çok ülkede yeşil vergi reformları gündeme gelmiş ve çevrenin korunmasına yönelik vergi düzenlemeleri yürürlüğe girmiştir (Şen ve Sağbaş, 2016, s. 490). Böylece kaynak dağılımında verimlilik sağlanarak, enerji, atık yönetimi, emisyon azaltımı gerçekleştirilerek sürdürülebilir bir çevre hedefine ulaşılabilecektir. Dolayısı ile yoksul kesimin çevresel sorunlar kaynaklı daha büyük problemler yaşamasının önüne geçilebilecektir.

Yoksulluk ile mücadele için uygulanabilecek bir diğer vergi uygulaması negatif ve pozitif dışsallıkların içselleştirilmesine ilişkindir. Dışsallıklar, fiyat mekanizması dışında bir ekonomik birinin başka bir ekonomik birimin faaliyetlerini olumlu ya da olumsuz yönde etkilemesi durumudur (Rosen ve Gayer, 2008, s. 71). Dışsallıkların varlığı durumunda piyasada etkin kaynak dağılımının sağlanamaması, gelir ve servet dağılımında eşitsizliklerin ortaya çıkması, ekonomik istikrarsızlıkların söz konusu olması nedeniyle devletler ilgili alanlara müdahale ederek piyasada optimal dengenin sağlanması için politikalar geliştirmektedir. Bu çerçevede negatif dışsalıkların olduğu alanlarda düzeltici vergiler ya da Pigou tipi vergiler, diferansiyel vergiler, atık bedel uygulaması vb. düzenlemeler ile kaynak dağılımında etkinsizlik sorunu giderilmeye çalışımaktadır (Stiglitz ve Rosengard, 2015, s. 139). Pozitif dışsallıkların söz konusu olduğu durumda ise devletler ilgili alanlara sübvansiyonlar ya da teşvik politikaları ile destek vererek özel fayda ile sosyal faydayı eşitleyebilecekleri uygulamaları benimsemektedir (Rosen ve Gayer, 2008, s. 83-84). 
Yoksulluğun ortadan kaldırılması için mücadele edilmesi gereken sorunlardan bir diğeri finansal istikrarsızlıklardır. Özellikle gelişmekte olan ülkelerde kısa vadeli sermaye hareketlerinin neden olduğu istikrarsızlıklar ekonomileri olumsuz yönde etkilemektedir. Küreselleşme sürecinin neden olduğu finansal hareketlilik sermaye hareketliliğini hızlandırarak gelişmekte olan ülkelerde finansal krizlerin artmasına yol açmıştır. Finansal serbestleşmenin ve finansal hareketliliğin yol açtığı olumsuz durumlar ile mücadele edilmesi ve ekonomiye istikrar kazandırılması için ulusal ve uluslararası düzeyde finansal işlemler vergisi, finansal faaliyet vergisi ve finansal istikrar katkı fonu gibi vergi uygulamaları J. M. Keynes gibi bilim insanlarının yanı sıra BM, Dünya Bankası, Uluslararası Para Fonu gibi uluslararası kuruluşlar tarafından da önerilmiştir. Böylece spekülatif amaçlı sermaye hareketliliğinin önüne geçilmesi amaçlanmaktadır. Finansal varlıkların genellikle yüksek gelir elde edenlerin elinde bulundurulduğu dikkate alındığında böyle bir vergi uygulaması ile ekonomiye istikrar kazandırılmasının yanı sıra yüksek gelir gruplarından düşük gelir gruplarına gelir ve servet transferi de gerçekleştirilebilecektir.

Yoksulluk ile mücadele için bir diğer öneri yoksullara yönelik yardım programlarının önemine vurgu yapan M. Friedman tarafından öne sürülen negatif gelir vergisidir. Negatif gelir vergisi, tüm toplumda minimum olarak kabul edilen düzeyin altında gelir elde eden herkese nakdi yardım yapılmasını ifade etmektedir (Friedman, 2008). Benzer şekilde Covid-19 pandemisi ile yoksulluk ile mücadele kapsamında ön plana çıkan önerilerinden bir diğeri evrensel temel gelirdir. Evrensel gelir fikri her ne kadar teknolojik gelişme süreçleri ve Covid- 19 ile birlikte yeniden ele alınan bir konu olsa da geçmişi oldukça eskidir. Evrensel temel gelir, vatandaşlık geliri, temel gelir gibi farklı adlar ile ele alınmış olmakla birlikte gelir ve servet dağılımında adaletin sağlanması amacı ile vatandaşların tamamına ya da gelir düzeyi belirli bir miktarın altında olanlara kamusal imkanlar dahilinde devletlerin nakdi yardım yapmasıdır (Ağdemir, 2021, s. 134-137). Evrensel temel gelir, bireysel, koşulsuz, herkese eşit miktarda verilen, düzenli, sürekli ve nakdi bir transferdir. Evrensel temel gelir düşüncesinin yoksulluk sorunu ile ilişkilendirilmesinin nedeni insanların temel ihtiyaçlarının karşılanmasına yönelik olmasıdır. Covid- 19 sürecinde devletler tarafından benimsenen sosyal yardım programlarının ve sosyal transferlerin bir çeşit evrensel temel gelir uygulaması olduğu düşünülmüş olsa da bu yardımların sadece pandemi dönemini kapsaması ve herkesi kapsamaması gibi nedenler ile evrensel temel gelirden farklı olduğu görülmektedir. Evrensel temel gelir, sosyal ve iktisadi refah düzeylerinin korunması ve maksimize edilmesi bakımından kısa dönemde ekonomik sorunlar konusunda geçici çözümler getirse de uzun dönemde işsizlik başta olmak üzere sosyo-ekonomik sorunlar konusunda beklenen düzeyde çözüm önerileri getirmeyeceği ve devlet bütçelerinde ek kaynak ihtiyacına neden olacağı düşüncesi nedeniyle uygulanabilir görülmemektedir.

Yoksulluk ile mücadele kapsamında üzerinde durulan bir diğer uygulama dijitalleşme sürecinin yansımaları ile yeni teknolojilerin üretim süreçlerine dahil edilmesi ile ilgilidir. Çalışanların önemli bir kısmının ücret geliri elde ettiği dikkate alındığında üretim süreçlerinde robotlaşmanın istihdam alanında önemli sorunlar ortaya çıkaracağı ve bu alanda çalışanların yoksullaşmasına neden olacağı düşünülmektedir. Dijitalleşme sürecinin ortaya çıkaracağı düşünülen bu olumsuz etkileri bertaraf etmek amacı ile önerilen uygulamalardan biri de robot vergisidir. Üretim sürecinde daha fazla robot teknolojisinin kullanılması hem mevcut 
vergi sistemlerinde gelir kaybına neden olacak hem de daha az emek kullanılması işsizlik sorunun artmasına yol açacaktır (Ivanov, 2017). Bu nedenle bu sürecin kamu maliyesinden ekonomik büyüme ve kalkınmaya hatta işgücü piyasalarına kadar pek çok alanda etkileri olması beklenmektedir. 1950'li yıllardan bu yana bahsi geçen robot vergisinin doğrudan uygulamasına yönelik hukuki, iktisadi ve sosyal alanda pek çok kısıt söz konusudur. Robotlaşmanın ücretlilerden elde edilen vergi gelirlerini azaltmasından ekonomide gelir dağılımında yol açacağı dengesizliğe kadar pek çok konuda etkileri olabileceği dikkate alınarak detaylı araştırmalar sonucunda mevcut vergi sistemlerinin yeniden tasarlanması önem taşımaktadır (Yıldız, 2019).

Yoksulluk ile mücadelede üzerinde durulması gereken bir diğer husus ise vergi kayıp ve kaçaklarını kontrol altına alabilecek uygulamalar benimsemektir. Kayıt dışı ekonominin boyutunun kontrol altına alınması ve vergi mükelleflerinin vergi ödeme istekliliklerinin artırılarak yasal ya da yasal olmayan yollarla vergi gelir kaybının önüne geçilmesi hem vergi hasılatını artıracak hem de gelir ve servet dağıtılımının daha adaletli bir şekilde gerçekleştirilebilmesi için daha fazla kaynak ekonomiye kazandırılabilecektir.

Yoksulluk sorunu ile mücadele kapsamında vergi politikalarından yararlanılması durumunda olumsuz etkilerle de karşılaşılması da mümkündür. Bu çerçevede özellikle benimsenen düzenlemelerin emek arzı üzerinde olumsuz etkiler yaratmayacak, kaynakların belirlenen hedefler doğrultusunda kullanılmasını sağlayacak, sınırlı sayıda yoksul yerine yoksul kesimin tamamını kapsayacak, sosyal refah artışı sağlayacak ve yoksul kesimin doğru bir şekilde belirlendiği uygulamaların tercih edilmesi önem taşımaktadır (Şenses, 2014, s. 265-272).

Sonuç olarak ekonomik kalkınma ve büyümenin sürdürülebilir olması için vergi sistemleri tasarlanırken mali alanda alınacak önlemlerin ilgili alanlara aktarılması, ekonomik ve sosyal konjonktürel dalgalanmaların göz önünde bulundurulması, gelir ve servet dağılımında eşitliğin sağlanması ve sosyal alanda verimlilik ortaya çıkaracak faaliyetlerin teşvik edilmesine yönelik vergisel düzenlemelerin benimsenmesi gerekmektedir. Burada asıl dikkat edilmesi gereken yoksulluk sorunu ile mücadele ederken vergisel düzenlemelerden yararlanıldığı durumda özellikle yoksul olarak nitelendirilen kesimin üzerinde daha fazla yük oluşturmamaktır (Grown, 2010, s. 1).

\section{Sonuç}

Yoksul olarak nitelendirilen bireylerin mali, ekonomik, sosyal ve kültürel alanda diğer bireylere kıyasla daha dezavantajlı durumda bulunması fırsat eşizsizliğine yol açarak insana yaraşır bir hayatın önünde engel teşkil etmektedir. Bu nedenle yoksullukla mücadele hatta yoksulluğun ortadan kaldırılması için devletler zaman zaman mevcut politikalarını revize ederek zaman zaman ise yeni politikalar ile ekonomik ve sosyal alanda müdahaleci ya da düzenleyici rol üstlenmektedir.

Yoksulluk ile mücadele için ulusal ve uluslararası düzeyde kalkınma hedeflerinin belirlenmesi, cinsiyet eşitsizliği ve ayrımcılığının önüne geçilmesi, endüstrileşme sürecinin kontrol altına alınması ve çağın gereklerine uygun sistemlerin mevcut sistemlere entegre edilmesi, yeterli ve gerekli enerji kaynaklarına herkesin kolayca erişiminin sağlanması, yeterli barınma, gıda, eğitim, sağlık gibi temel intiyaçların karşılanmasına ilişkin destek ve teşvik programlarının 
uygulanması, ekonomideki dengesizlik ve istikrarsılık sorunları ile mücadele edilerek optimalitenin sağlanması ve toplumdaki tüm bireylerin hayatını insana yaraşır şekilde sürdürmesine imkan sağlayacak geçim kaynaklarının sunulması önem taşımaktadır. Bu kapsamda devletler iktisat ve maliye politikası araçlarını yaygın olarak kullanmaktadır. Böylece toplumsal refahın maksimize edilmesi amacı doğrultusunda her bir bireyin temel ihtiyaçlarını karşılayabilecek düzeyde hizmet sunumu gündeme gelmiş ve dolayısıyla bu mal ve hizmetlerin sunulabilmesi için daha fazla harcama yapılmaya başlanmıştır. Artan kamu harcamaları daha fazla gelir ihtiyacı ortaya çıkarmış ve kamu gelirleri arasında en büyük paya sahip olan vergilere yönelik politikalar geliştirilmiştir.

Vergilerin bir sosyal politika aracı olarak kullanılması yolu ile yoksulluk ile mücadele kapsamında mevcut vergi sistemlerinin sosyal amaçlar gözetilerek düzenlenmesi yolu tercih edebilmekte ya da doğrudan yoksulluk ile mücadele etmeye yönelik yeni vergisel düzenlemeler benimsenebilmektedir.

Vergi sistemlerinin adalet, eşitlik, açıklık, genellik gibi ilkeler çerçevesinde tasarlanması başta yoksulluk olmak üzere pek çok toplumsal sorunun çözülmesinde önem taşımaktadır. Burada önemli olan sistemler tasarlanırken bireylerin gelir ve servet farklılıklarının dikkate alınmasıdır. Vergi ödeme gücü çerçevesinde, en az geçim indirimi, vergi sistemlerinin ücret geliri lehine düzenlenmesi, artan oranlı vergilerden yararlanılması, vergi sistemlerinin dolaysız vergilere ağılık verilerek tasarlanması gibi ulusal düzeyde sübjektif vergi düzenlemelerinin uygulamalarda yer alması sosyal adalet ve sosyal refahın maksimizasyonu bakımından önem taşımaktadır. Ayrıca küresel düzeyde ilk sıralarda yer alan yoksulluk sorunun çözülmesi için düzeltici vergiler, finansal işlemler vergisi, karbon vergisi, robot vergisi gibi küresel düzeyde uygulanacak vergi düzenlemelerinin de etkili olabileceği göz ardı edilmemelidir.

Sonuç olarak devletlerin vergi politikalarını transfer politikaları ile destekleyerek gelir ve servetin yeniden dağıtımında adalet ve eşitliğin sağlanmasına yönelik dengeleyici politikalar ile yoksulluk sorununa çözüm getirmesi beklenmektedir. Ülkelerin mevcut ekonomik, sosyal ve politik durumları göz önünde bulundurularak maliye ve iktisat politikalarının şekillendirilmesi ve amaçların gerçekleştirilmesi için uygun politika araçlarının detaylı analizler sonucunda belirlenmesi sürdürülebilirlik hedefleri ile uyumlu sonuçlara ulaşılmasına imkan sağlayacaktır.

\title{
"Yoksulluk ile Mücadelede Vergi Politikalarının Rolü" Başlıklı Makalenin Araştırma ve Etik Beyanı Bilgileri
}

\author{
Bu çalışma "Araştırma ve Yayın Etiği" değerlerine uygun olarak \\ hazırlanmıştır
}

Bilgilendirme Çalışma SADAB tarafından 25-27 Haziran 2021 tarihinde düzenlenen "SADAB 9th International Online Conference on Social Research and Behavioral 


\begin{tabular}{|c|c|}
\hline & $\begin{array}{l}\text { Sciences" adlı sempozyumda sunulan "Sosyal Bir Sorun Olarak Yoksulluk Ille } \\
\text { Mücadelede Kullanılan Vergi Politikaları" başlıklı sözlü bildiriden türetilmiştir. }\end{array}$ \\
\hline $\begin{array}{l}\text { Yazar Çıkar } \\
\text { Çatışması Beyanı }\end{array}$ & Çalışmada herhangi bir çıkar çatışması bulunmamaktadır. \\
\hline $\begin{array}{l}\text { Yazar Katkı Oranı } \\
\text { Beyanı }\end{array}$ & $\begin{array}{l}\text { Çalışmayı şahsım İrem DiDiNMEZ olarak tek başıma hazırladığımı beyan } \\
\text { ederim. }\end{array}$ \\
\hline Teşekkür & Çalışmada teşekkür gerektiren bir durum bulunmamaktadır. \\
\hline $\begin{array}{l}\text { Etik Kurul Onay } \\
\text { Belgesi }\end{array}$ & Çalışmada etik kurul onayı gerekmemektedir. \\
\hline
\end{tabular}

\section{Kaynakça}

Ağdemir, Z. (2021). Otomasyon, Bilişsel Kapitalizm, Pandemi ve Devlet Maliyesi: Vatandaşlık Geliri Tartışmaları. Ş. Karabulut içinde, Maliye Biliminde Gelenekçi ve Yenilikçi Yaklaşım ve Gelişmeler: Kamu Harcamaları, Kamu Gelirleri, Bütçe (s. 129-148). Ankara: Gazi Kitabevi.

Akdoğan, A. (2016). Kamu Maliyesi. Ankara: Gazi Kitabevi.

Alcock, P. (2008). Social Policy in Britain. New York: Palgrave Macmillan.

Atherton, C. R. (1992). A Pragmatic Approach to the Problem of Poverty. Social Work, 37(3), 197-201.

Aydın, M., \& Türgay, T. (2011). Yoksullukla Mücadelde Vergi Politikası ve Türkiye. Süleyman Demirel Üniversitesi Iktisadi ve Idari Bilimler Fakültesi Dergisi, 16(1), 249-274.

Bhagwati, J. N. (1988). Poverty and Public Policy. World Development, 16(5), 539-555.

Bourguignon, F. (2004). The Poverty-Growth-Inequality Triangle. The World Bank.

Briggs, A. (1961). The Welfare State in Historical Perspective. European Journal of Sociology /Archives Européennes de Sociologie / Europäisches Archiv für Soziologie, 2, 221258.

Buğra, A. (2008). Kapitalizm, Yoksulluk ve Türkiye'de Sosyal Politika. İstanbul: Iletişim Yayınları.

Cano-Hila, A. B. (2020). Urban Poverty. Oxford Bibliographies.

Cardoso, E., \& Helwege, A. (1992). Below the line: Poverty in Latin America. World Development, 20(1), 19-37.

Drakakis-Smith, D. (1996). Third World Cities: Sustainable Urban Development IIPopulation, Labour and Poverty. Urban Studies, 33(4-5), 673-701. 
Edizdoğan, N., Çetinkaya, Ö. \& Gümüş, E. (2013). Kamu Maliyesi. Bursa: Ekin Basım Yayın Dağıtım.

Flora, P., \& Heidenheimer, A. J. (2009). Modernization, Democratization and the Development of Welfare States in Western Europe. P. Flora, \& A. J. Heidenheimer içinde, The Development of Welfare States in Europe and America (s. 37-80). New Jersey: The State University.

Friedman, M. (2008). Kapitalizm ve Özgürlük. İstanbul: Plato Film Yayınları.

Grown, C. (2010). Taxation and Gender Equity A Conceptual Framework. C. Grown, \& I. Valodia içinde, Taxation and Gender Equity A Comparative Analysis of Direct and Indirect Taxes in Developing and Developed Countries (s. 1-22). London and New York: Routledge, IDRC.

Häusermann, S. (2012). The Politics of Old and New Social Policies. Zurich Open Repository and Archive. University of Zurich.

Headey, B., Goodin, R. E., Muffels, R., \& Dirven, H.-J. (1999). Real Worlds of Welfare Capitalism. Cambridge University Press.

Helgason, K. S. (2020). The Economic and Political Costs of Population Displacement and Their Impact on the SDGs and Multilateralism. DESA Working Paper No. 167, ST/ESA/2020/DWP/167. United Nations Economic and Social Affairs.

Horejsi, C. J., \& Sheafor, B. W. (2015). Sosyal Hizmet Uygulaması. Ankara: Nika Yayınevi.

Huber, E., \&Stephens, J. D. (2006). Combating Old and New Social Risks. K. Armingeon, \& G. Bonoli içinde, The Politics of Post-Industrial Welfare States: Adapting Post-War Social Policies to New Social Risks (s. 143-168). London: Routledge.

ILO. (2008). Promotion of rural employment for poverty reduction. Geneva: International Labour Office.

Ivanov, S. (2017). Robonomics-Principles, Benefits, Challenges,Solutions. Yearbook of Varna University of Management, 10, 283-293.

Karabacak, Y. (2012). Sosyal Politika Aracı Olarak Vergilemenin İşlevleri: Türkiye Örneği. istanbul Üniversitesi Iktisat Fakültesi Mecmuası, 62(2), 223-252.

Lipton, M. (1997). Defining and Measuring Poverty: Conceptual Issues. New York: UNDP Human Development Paper.

Musgrave, R. (1959). The Theory of Public Finance. New York: McGraw-Hill.

Mutluer, K., Kuzeyli Dayanç, N. N. (2019). Vergi Hukuku Genel ve Özel Hükümler. Ankara: Yetkin Yayınları.

OHCHR. (2004). Human Rights and Poverty Reduction. A Conceptual Framework. New York and Geneva: United Nations.

Rosen, H. S., \& Gayer, T. (2008). Public Finance. Singapore: McGraw Hill Internationa Edition. 
Rowntree, B. S. (1901). Poverty: A Study of Town Life. New York: Macmillan and Co.

Saraceno, C. (2002). Social Assistance Dynamics in Europe: International and Local Poverty Regimes. Bristol, UK: Policy Press.

Sen, A. K. (2002). Rationality and Freedom. Cambridge, MA: Belknap Press of Harvard University Press.

Seyyar, A. (2002). Sosyal Siyaset Terimleri (Ansiklopedik Sözlük). İstanbul: Beta Basım Yayım.

Sinn, H.-W. (1994). A theroy of welfare state. NBER Working Paper Series Working Paper No. 4856. National Breau of Economic Research.

Stiglitz, J. E., \& Rosengard, J. K. (2015). Economcics of the Public Sector. New York, London: W. W. Norton\& Compnay Inc.

Şen, H., Sağbaş, İ. (2016). Vergi Teorisi ve Politikası. Ankara: Kalkan Matbaacılık San. Tic. ve Ltd. Şti.

Şenses, F. (2014). KüreselleG̦menin Öteki Yüzü Yoksulluk. İstanbul: İletişim Yayınları.

Topgül, S. (2013). Türkiye'de Yoksulluk ve Yoksulluğun Kadınlaşması. C.Ü. Iktisadi ve Idari Bilimler Dergisi, 14, 277-296.

Türkiye Cumhuriyeti Cumhurbaşkanlığı Strateji ve Bütçe Başkanlı̆̆ı. (2019). Sürdürülebilir Kalkınma Amaçları Değerlendirme Raporu .

TÜSIAD. (2012). Dolaylı ve Dolaysız Vergilerin Türk Mali Sistemi Içerisindeki Yeri: Siyasal, Sosyal ve Ekonomik Sonuçlar. TÜsiAD.

UNDP. (1997). Human Development Report 1997. New York: Oxford University Press.

UNDP. (1998). Human Development Report 1998. New York: Oxford University Press.

United Nations. (2020). The Sustainable Development Goals Report 2020.

United Nations. (2021a). The Sustainable Development Goals Report 2021. United Nations.

United Nations. (2021b). Sustainable Development Goals Progress Chart 2021. United Nations.

World Commission on Environment and Development. (1987). Our Common Future. Oxford: Oxford University Press.

Yıldız, Y. (2019). Robot Vergisi: Yeni Nesil Bir Maliye Politikası Aracı. Maliye Dergisi, 177, 299329.

Zastrow, C. (2015). Sosyal Hizmete Giriş. Ankara: Nika Yayınevi. 


\section{The Role of Tax Policies to Fight Against Poverty}

İrem DIDINMEZ

\section{Extended Abstract}

The fact that all countries, regardless of development level, experience the problem of poverty that leads to handling poverty and are fighting against poverty at the national and international levels. Since poverty is regarded as a global problem affecting countries with different levels of development and has economic, social, and political importance, the scope of the concept of poverty is extended. In this context, poverty is a concept that has varying scopes, causes, and contents throughout history. Poverty refers to the lack of needs perceived as a society and the living standards of people living in poverty are considered to be below the average minimum standard.

Although there are many studies on poverty in the literature, these studies focus on poverty and the fight against poverty from an economic perspective. Therefore, it is aimed to contribute to the literature by focusing on the social aspect of poverty and assessing the use of tax regulations in fighting the problem of poverty as a social policy instrument. Within this context, the study firstly focuses on the theoretical framework of poverty; then the extent of poverty is explained in relation to the sustainable development goals. Then the relationship between social policies and poverty is discussed. In the following section, approaches to fighting poverty are discussed and finally, the role of taxes as a social policy instrument in fighting poverty is assessed.

In order to fight the problem of poverty firstly, the causes of poverty must be determined. According to Zastrow (2005), who comprehensively discusses the causes of poverty, poverty can be caused by economic factors such as problems in the labor market, imbalances in income distribution, insufficient investments in healthcare and education, competition in the international arena, crises, and inflation as well as demographic factors, socio-psychological factors, and social factors such as social and individual problems, population, and gender discrimination.

Poverty does not only mean having insufficient resources to survive physically but is also expressed as a set of conditions that prevent the full integration into a community, taking into account living standards. Therefore, it is important to use social policy instruments actively when fighting the problem of poverty. Within this context, in order to fight against poverty and even to eliminate poverty, states revise their existing policies from time to time 
and sometimes take an interventionist or regulatory role in the economic and social field with new policies.

In order to fight the problem of poverty, it is important to determine national and international development goals, preventing gender inequality and discrimination, control the industrialization process, and integrating the systems that are suitable for the requirements of the age into the current systems, ensure that everyone has easy access to adequate and necessary energy resources, implement support and incentive programs for meeting basic needs such as adequate shelter, food, education, and healthcare, ensure optimality by combating the problems of imbalance and instability in the economy and provide livelihoods that will allow all individuals in the society to lead their lives in a decent way. Within this framework, the study reveals the necessity that the policy instruments developed to fight the problem of poverty should be versatile. Within this context, states widely use economic and fiscal policy instruments. Thus, in line with the aim of maximizing social welfare, the aim of providing services at a level that can meet the basic needs of each individual led to an increase in expenditures to provide these goods and services. Increasing public expenditures have created a need for more revenue and policies have been developed for taxes, which have the largest share in public revenues.

Within the framework of ability to pay taxes, in terms of maximization of social justice and social welfare, it is important that subjective tax regulations at the national level such as minimum living allowance, regulation of tax systems in favor of income, use of graduated taxes, designing tax systems with a focus on direct taxes. In addition, it should not be ignored that tax regulations to be implemented at the global level such as corrective taxes, financial transactions tax, carbon tax, and robot tax may be effective in solving the problem of poverty, which is among the top problems at the global level.

As a result, it is expected that states would support their tax policies with transfer policies and provide a solution to the problem of poverty using balancing policies aimed at ensuring justice and equality in the redistribution of income and wealth. Determining the appropriate policy instruments as a result of detailed analyzes for shaping fiscal and economic policies and realizing the objectives by considering the current economic, social, and political conditions of the states will make it possible to gain results that are compatible with sustainability goals. 